\title{
Croton mubango Müll. Arg.: Its Botany, Ethnomedicinal Uses and Pharmacological Properties
}

\author{
Alfred Maroyi
}

Medicinal Plants and Economic Development (MPED) Research Centre, Department of Botany, University of Fort Hare, Private Bag X1314, Alice 5700, South Africa

\begin{abstract}
Croton mubango is widely used as traditional medicine in tropical Africa. The potential of C. mubango as traditional medicine, its botany, chemical and pharmacological activities are reviewed. The literature relevant to the study was obtained from scientific databases such as BioMed Central (BMC), Web of Science, Google Scholar, Scopus, Science Direct, PubMed, Springerlink and Scielo. Other supplementary literature such as books, book chapters, theses, conference papers and other scientific publications were obtained from the University of Fort Hare Library and dissertation search engines such as EThOS, OATD, ProQuest and Open-thesis. Literature search revealed that the bark, fruits, leaves and roots of $C$. mubango are commonly used as traditional medicines for abdominal pain, diarrhoea, dysentery, fever, hernia, intestinal worms, malaria, rheumatism, toothache, tuberculosis and as purgative. Phytochemical compounds isolated from C. mubango include alkaloids, flavonoids, reducing sugars, saponins, steroids, tannins, terpenes and triterpenes. Pharmacological studies on C. mubango indicate that the species has in vitro and in vivo antiplasmodial activities. Several medicinal applications and therapeutic potentials of $C$. mubango have been demonstrated in this study although the majority of them still need pharmacological validation.
\end{abstract}

Keywords: Africa, antiplasmodial, Croton mubango, ethnomedicinal uses, Euphorbiaceae.

\section{INTRODUCTION}

Croton mubango Müll. Arg. is a member of the Euphorbiaceae or spurge family, comprising more than 1200 species worldwide [1]. There has been a tremendous interest in the medicinal uses and pharmacological properties of Croton L. species in Africa, Asia and South America [2-7]. Popular medicinal applications of Croton species include its use as herbal medicine for weight-loss, malaria, constipation, digestive problems, inflammation, hypercholesterolemia, dysentery, ulcers, cancer, external wounds, pain, diabetes, intestinal worms, hypertension and fever [2]. Phytochemical analyses of Croton species extracts showed the prevalence of diterpenes, particularly clerodanes, cembranoid, halimanes, kauranes, labdanes, phorbol esters, trachylobanes and sarcopetalanes [2]. Other classes of phytochemical compounds isolated from Croton species include alkaloids, cardenolides, flavonoids, proanthocyanidins, saponins and volatile oils containing monoterpenes and sesquiterpenoids [2,8]. Pharmacological properties of Croton species include hypolipidemic, hypoglycaemic, antioestrogen, anticancer, anti-hypertensive, anti-inflammatory, antimalarial, antimicrobial, antispasmodic, antiulcer, antiviral and myorelaxant [2].

*Address correspondence to this author at the Medicinal Plants and Economic Development (MPED) Research Centre, Department of Botany, University of Fort Hare, Private Bag X1314, Alice 5700, South Africa;

Tel/Fax: 0027719600326; E-mail: amaroyi@ufh.ac.za
Research by Schmelzer and Gurib-Fakim [3] revealed that nineteen Croton species are regarded as important herbal medicines in tropical Africa, these included C. antanosiensis Leandri, C. aubrevillei J. Léonard, C. barorum Leandri, C. decaryi Leandri, C. geayi Leandri, $C$. haumanianus J. Léonard, $C$. jatrophoides Pax, C. lobatus L. (now a synonym of Astraea lobata (L.) Klotzsch), C. macrostachyus Hochst. ex Delile, C. mauritianus Lam., C. membranaceus Müll. Arg., C. menyharthii Pax, C. mubango, C. myriaster Baker, C. nitidulus Baker, C. penduliflorus Hutch., C. sakamaliensis Leandri, C. sylvaticus Hochst. ex C. Kruass and C. tiglium L. Research by Maroyi [5] showed that $C$. sylvaticus is herbal medicine for about 24 human and animal diseases in tropical Africa and the plant species is characterized by antibacterial, antifungal, antiinflammatory, antioxidant, larvicidal activities and effects on the central nervous system. Croton megalocarpus is another popular traditional herbal medicine in tropical Africa, used to treat about 41 human and animal diseases such as intestinal worms, malaria, gastro-intestinal tract diseases, respiratory diseases, fever, colds, fever, wounds and cough [6]. Several classes of chemical compounds such as saponins, fatty acids, reducing sugars, triterpenoids, alkaloids, phenols, clerodane diterpenoids, glycosides, tannins, flavonoids, sterols and flavones have been isolated from plant parts of $C$. megalocarpus [6]. Croton macrostachyus is used as herbal medicine for at least 81 human and animal diseases such as abdominal 
pains, cancer, gastro-intestinal disorders, malaria, pneumonia, sexually transmitted infections, skin infections, typhoid and wounds, and as ethnoveterinary medicine [7]. Several classes of chemicals such as alkaloids, amino acids, anthraquinones, carbohydrates, cardiac glycosides, coumarins, essential oil, fatty acids, flavonoids, phenolic compounds, phlobatannins, polyphenols, phytosteroides, saponins, sterols, tannins, terpenoids, unsaturated sterol, vitamin $\mathrm{C}$ and withanoides have been identified from the plant species [7]. Ethnopharmacological studies on $C$. macrostachyus revealed several biological activities such as anthelmintic, antibacterial, antimycobacterial, antidiarrhoeal, antifungal, anticonvulsant and sedative, antidiabetic, antiinflammatory, antileishmanial, antioxidant, antiplasmodial and larvicidal effects [7]. It is within this context that the medicinal uses, phytochemistry and biological activities of C. mubango were evaluated. Therefore, the present study is aimed at collating fragmented information on medicinal uses, chemistry, biological activities and toxicology of the plant species. The information to be generated from this study focusing on the ethnopharmacology of $C$. mubango will highlight the potential of the species as a possible source of several pharmaceutical and health products in tropical Africa.

\section{BOTANICAL DESCRIPTION OF THE SPECIES}

Croton mubango has been recorded in Angola, Central African Republic, Democratic Republic of Congo (DRC) and Gabon. Croton mubango has been recorded in margins of dense forest, secondary forest, savanna woodland and sometimes the species is planted in villages [3,9]. According to Smith [10] in Angola and DRC, C. mubango is difficult to distinguish from a closely related species, C. megalocarpus Hutch. The two species differ in the smaller and more globose fruit, and in the non-lobulate style-segments.

Croton mubango is a monoecious large shrub to a small to medium-sized tree up to $17 \mathrm{~m}$ in height with a bole up to $30 \mathrm{~cm}$ in diameter [9]. Croton mubango is characterized by widely spreading dense branches, drooping twigs covered with dense, scaly, short and stellate hairs. The leaves are alternate, simple, dark green, entire, ovate-elliptic to cordate and with two large glands at the base. The leaves are hairy above, scaly and grey below, sometimes with hairs on the midrib and petiole. The inflorescence of $C$. mubango is a slender, terminal raceme covered with scales, with male flowers in the upper part and female flowers at the base of the inflorescence. Flowers are unisexual, regular, white in colour with triangular sepals and ovate-elliptical petals [9]. The fruit is a capsule, spherical in shape, 18-23 mm in diameter, covered with dense, short scales, with ellipsoid seeds which are usually brown in colour.

\section{MEDICINAL USES}

In Angola, the leaf, bark and root infusions of $C$. mubango are taken orally as traditional medicines for fever, intestinal worms, rheumatism and stomach pain [11] as shown in Table 1. In DRC, the bark infusion is used as remedy for toothache, pain in the joints, hernia, skin infections and haemorrhoids [12]. The entire body is rubbed with a bark maceration or infusion of $C$. mubango as a tonic and a bark infusion is taken as remedy for gastritis and painful menstruation periods [12]. The bark of $C$. mubango is taken orally mixed with powdered seeds of Monodora myristica (Gaertn.) Dunal as remedy for abdominal pains and to expel intestinal worms [12,13]. Bark, leaf, powdered root or a root maceration of $C$. mubango are taken orally as remedies for diarrhoea and dysentery $[14,15]$. Stem bark infusion or decoction of $C$. mubango is widely used in DRC as remedy for abdominal pain, blennorrhea, gonorrhoea, malaria, odema, splenomegaly and tuberculosis [14,16-18]. Leaf infusions of $C$. mubango are taken orally as remedy for convulsions and as a vermifuge $[15,19]$ while root macerations or decoctions are taken orally as remedies for cough, dysentery and pain $[14,15]$. Young fruits of C. mubango are taken orally in palm wine as a laxative [14] and fruit powder is taken orally mixed with food as a stimulant [15].

Based on ethnomedicinal information from literature, it appears that $C$. mubango is most commonly used as herbal medicine for abdominal pain, diarrhoea, dysentery, fever, hernia, intestinal worms, malaria, rheumatism, toothache, tuberculosis and as purgative (Figure 1). Global attention and resources have been focused on diarrhoea, dysentery, intestinal worms, malaria and tuberculosis which are major diseases that are prevalent in tropical Africa [20-22]. Research by Maroyi [5] revealed that a related species, C. sylvaticus is a popular herbal medicine in tropical Africa for abdominal pain, fever, malaria, rheumatism, tuberculosis and as a purgative. While $C$. megalocarpus is used against diarrhoea, dysentery, fever, intestinal worms and as a purgative [6]. Similarly, C. macrostachyus is used for abdominal pain, diarrhoea, dysentery, intestinal worms, malaria, rheumatism and as a purgative [7]. In South Africa, $C$. gratissimus Burch. and C. sylvaticus are both known as "koorsbessie" in Afrikaans, that is, "koors" meaning 
Table 1: Ethnomedicinal Uses of Croton mubango

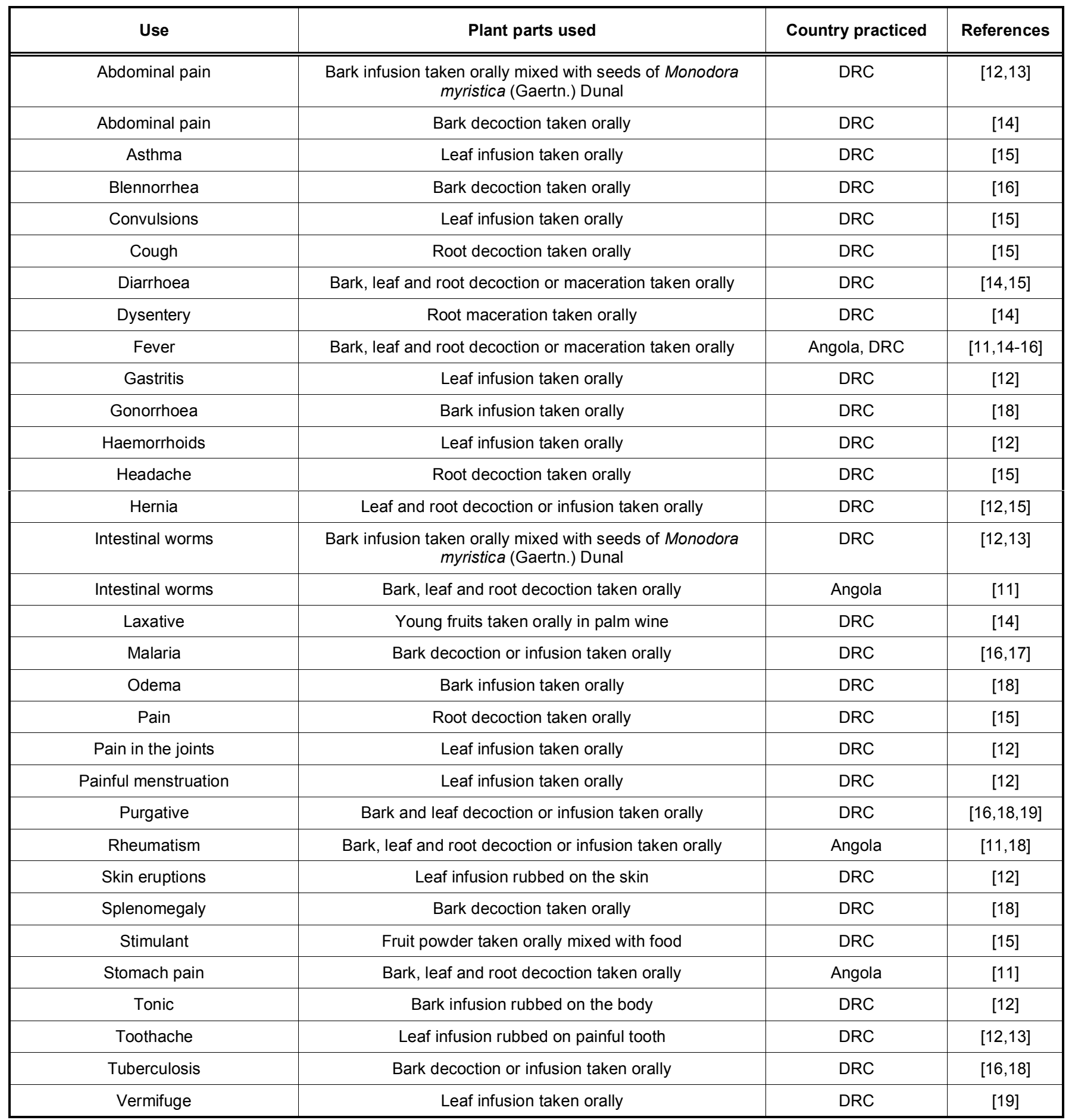

"fever" and "bessie" meaning "berry", as the two species are widely used as remedies for fever in the country [23].

\section{PHYTOCHEMICAL CONSTITUENTS OF $C$ MUBANGO EXTRACTS}

Preliminary phytochemical screening of $C$. mubango extracts revealed the presence of flavonoids, steroids and/or triterpenes, reducing sugars and saponins [14]. In another study by Mesia et al. [17] alkaloids, saponins, tannins, terpenes and steroids were identified from the stem bark of $C$. mubango. Mesia et al. [17] argued that alkaloids and terpenoids identified from the stem extracts of the species could be responsible for the documented antimalarial activities exhibited by the extracts, since chemicals belonging to this group of phytochemical classes exhibit antimalarial 


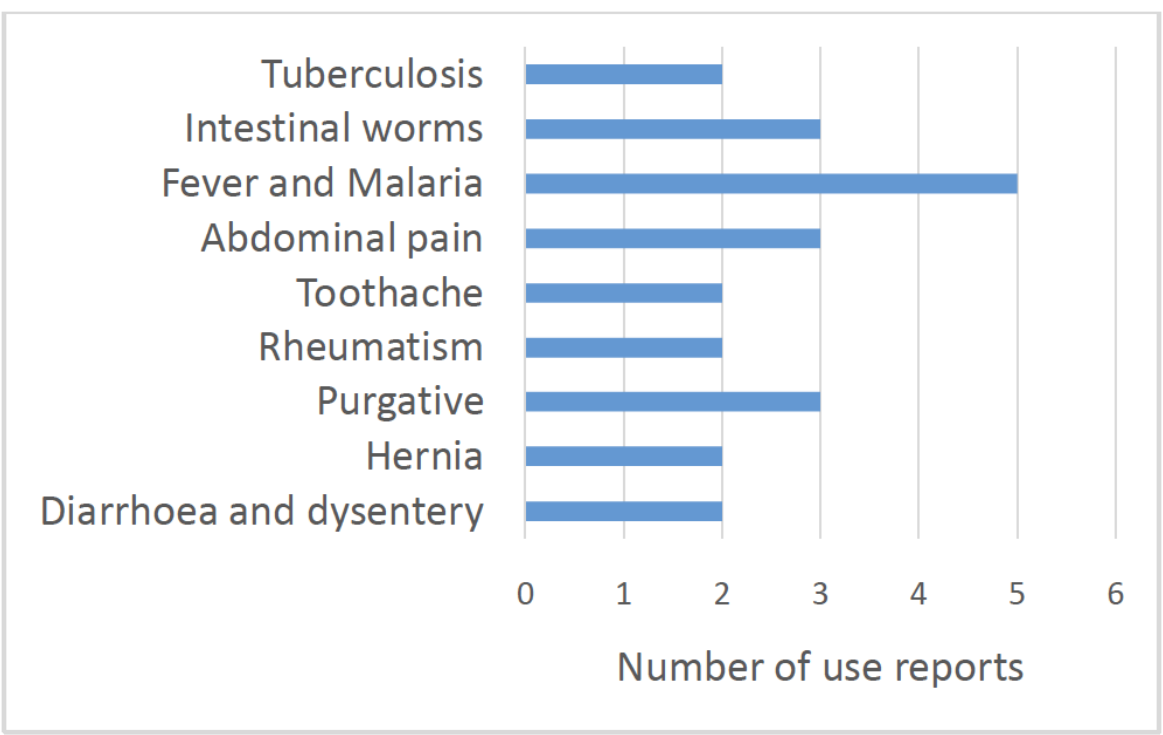

Figure 1: Medicinal uses of C. mubango.

activities. According to Mahajan et al. [24] alkaloids have biological and physiological effect that renders them valuable herbal medicines against several diseases such as cardiac dysfunction, malaria, cancer and diabetics. Alkaloids isolated from Heimia salicifolia (Kunth) Link showed antimalarial activities with median inhibitory concentrations $\left(\mathrm{IC}_{50}\right)$ values of ranging from 6.7 to $10.9 \mu \mathrm{M}$ [25]. A diterpenoid, steenkrotin identified from a leaf ethanol extract of $C$. steenkampianus Gerstner demonstrated good antiplasmodial activities with the $I_{50}$ values ranging from $9.1 \mu \mathrm{M}$ to $>30 \mu \mathrm{M}$ against four strains of Plasmodium falciparum, two chloroquine-susceptible strains (D10) and (D6), and the two chloroquine-resistant strains (Dd2) and (W2) [26]. Several antiplasmodial diterpenes have been identified from other Croton species including 8,9-secokaurane which was identified from $C$. kongensis Gagnep. that demonstrated activities against Plasmodium falciparum $\mathrm{K} 1$ strain with the $\mathrm{IC}_{50}$ values ranging from $1.0 \mu \mathrm{g} / \mathrm{mL}$ to $2.8 \mu \mathrm{g} / \mathrm{mL}$ [27] and geranyl geraniol which was isolated from $C$. lobatus (now a synonym of $A$. lobata) extracts and inhibited Plasmodium falciparum with $\mathrm{IC}_{50}$ value of $3.7 \mu \mathrm{M}[28]$.

\section{PHARMACOLOGICAL ACTIVITIES OF C. MUBANGO EXTRACTS}

Mesia et al. [17] evaluated antimalarial activities in vitro of crude, methanol, dichloromethane, petroleumether, chloroform, ethyl-acetate, n-butanolic and stem bark aqueous extracts of $C$. mubango against Plasmodium falciparum and in vivo activities were evaluated in a four-day suppressive test against the Plasmodium berghei berghei infections in Albino mice with $10 \%$ ethanol and quinine dihydrochloride as negative and positive controls, respectively. The methanol, chloroform, dichloromethane, petroleumether, ethyl-acetate, n-butanolic and aqueous extracts demonstrated antimalarial activities with $\mathrm{IC}_{50}$ values ranging from $<0.1 \mu \mathrm{g} / \mathrm{ml}$ to $7.8 \mu \mathrm{g} / \mathrm{ml}$ [17]. In vivo test results revealed that, at a daily oral dose of $200 \mathrm{mg} / \mathrm{kg}$, the ethyl-acetate, petroleum-ether, dichloromethane, chloroform and water-soluble C. mubango extracts produced $>80 \%$ chemosuppression of the parasitaemias by the fourth day. The water extract of C. mubango produced a lower but significant inhibition of parasitaemia ranging from $60 \%$ to $80 \%$ by day 4 [17]. These findings corroborate the rationale for the traditional application of $C$. mubango against malaria in the DRC $[16,17]$.

Antimalarial activities have been demonstrated by several other Croton species. The dichloromethane leaf and stem extracts of $C$. guatemalensis Lotsy demonstrated in vitro activities against the chloroquinesensitive (NF54) and the chloroquine-resistant (K1) strains of Plasmodium falciparum, with the $\mathrm{IC}_{50}$ values of $19 \mu \mathrm{g} / \mathrm{ml}$ to $27 \mu \mathrm{g} / \mathrm{ml}$ and $20 \mu \mathrm{g} / \mathrm{ml}$ to $25 \mu \mathrm{g} / \mathrm{ml}$, respectively [29]. Similarly, the leaf and stem methalonic and aqueous extracts of $C$. guatemalensis significantly reduced Plasmodium berghei berghei parasitaemia in infected Albino mice [28]. In a different study, Prozesky et al. [30] showed that stem bark choloroform extract of $C$. pseudopulcheltus Pax was active against the chloroquine-sensitive strain of Plasmodium falciparum (PfUP), with the $\mathrm{IC}_{50}$ value of $3.5 \mu \mathrm{g} / \mathrm{ml}$. The aerial parts and root methalonic and dichloromethane extracts of $C$. lobatus (now a synonym of $A$. lobata) demonstrated antimalarial activities against chloroquine sensitive Plasmodium 
falciparum 3D7 with the $\mathrm{IC}_{50}$ values of $0.4 \mu \mathrm{g} / \mathrm{ml}$ to 7 $\mu \mathrm{g} / \mathrm{ml}$, and against chloroquine-resistant Plasmodium falciparum $\mathrm{K} 1$, with the $\mathrm{IC}_{50}$ value of $<5 \mu \mathrm{g} / \mathrm{ml}$ [31]. The aerial parts ethanol extracts of $C$. leptostachyus Kunth demonstrated anti-malarial activities against Plasmodium falciparum with the $\mathrm{IC}_{50}$ value of $2.1 \pm 0.2$ $\mu \mathrm{g} / \mathrm{mL}$ [32]. Several root extracts and fractions of $C$. zambesicus Müll. Arg. (now a synonym of $C$. gratissimus) exhibited antimalarial activities of 79-86\% parasitaemia suppression at the doses of 27-81 $\mathrm{mg} / \mathrm{kg} / \mathrm{day}$ ) against Plasmodium berghei in Albino mice [33]. According to Mohammed et al. [34] a dose dependency in the suppression of Plasmodium berghei in Albino mice was demonstrated by C. macrostachyus water and methanol extracts at a daily doses of 200 , 400 and $600 \mathrm{mg} / \mathrm{kg}$.

\section{TOXICOLOGICAL ACTIVITIES}

The toxic effects of stem bark aqueous extracts of C. mubango were evaluated in uninfected Swiss mice by starving mice for $24 \mathrm{~h}$ prior to treatment by gavage with a single dose of the stem bark extract with distilled water as control [17] The stem bark aqueous extracts of $C$. mubango demonstrated signs of toxicity in Swiss mice, with the median lethal doses $\left(\operatorname{LD}_{50}\right)$ values of 350 $\mathrm{mg} / \mathrm{kg}$ and $900 \mathrm{mg} / \mathrm{kg}$ in female and male Swiss mice, respectively. The authors demonstrated that the aqueous extract significantly increased the serum concentrations of glutamate-oxaloacetate transaminase (GOT) and glutamate-pyruvate transaminase (GPT) in both female and male Swiss mice, respectively, but showed no effect on the blood levels of urea or creatinine [17]. The oral administration of aqueous stem bark extract of $C$. mubango in doses exceeding $250 \mathrm{mg} / \mathrm{kg}$ lead to signs of toxicity which included palpitations, asthenia and diarrhoea. The Swiss mice that were given 5, 4, 3 and $2 \mathrm{~g}$ of stem bark extract per $\mathrm{kg}$ as a single dose died after 1, 2, 3 and 4 days, respectively [17]. The female Swiss mice that were given $1 \mathrm{~g}$ of the aqueous stem bark extract of $C$. mubango/kg and $66 \%$ of the Swiss male mice given the same treatment died after 5 days. These results indicate that $C$. mubango stem bark extract could be more toxic to female Swiss mice than male. The observed toxicity of $C$. mubango stem bark extracts could probably due to the cytotoxic terpenoids that have been isolated from the species [17]. Several Croton species are known to be toxic to some mammalian species probably due to terpenic compounds such as crotonin and derivatives that have been isolated from the species [35-40]. Based on these findings, future toxicological research should focus on assessing toxicological activities of the crude extracts and phytochemical compounds that have been isolated from the bark, fruits, leaves and roots of the species.

\section{CONCLUSION}

The fruits, bark, leaves and roots of $C$. mubango are widely used as herbal medicine for abdominal pain, diarrhoea, dysentery, fever, hernia, intestinal worms, malaria, rheumatism, toothache, tuberculosis and as purgative. However, it is clear that several medicinal applications still require ethnopharmacological validation. These include the use of $C$. mubango as herbal medicine for intestinal worms, microbial infections and pain. Further pharmacological evaluations should focus on anthelmintic, antiinflammatory, antimicrobial, antinociceptive and antioxidant activities of the plant extracts as well as compounds isolated from the species. There is also dearth of scientific evidence on the toxicity of $C$. mubango, except a toxicological evaluation carried out by Mesia et al. [17]. Very little information is available in ethnopharmacological literature focusing on the poisonous properties of the species and it is important that a safety profile of $C$. mubango is established as this is one of the species widely used as herbal medicine in tropical Africa.

\section{AUTHORS' CONTRIBUTIONS}

I declare that this work was done by the author named in this article.

\section{CONFLICT OF INTEREST}

No conflict of interest is associated with this work.

\section{ACKNOWLEDGEMENTS}

The author would like to express his gratitude to the National Research Foundation, South Africa (NRF grant number T398) and Govan Mbeki Research and Development Centre (GMRDC, grant number C169), University of Fort Hare for financial support to conduct this study.

\section{REFERENCES}

[1] Van Ee BW, Riina R, Berry PE. A revised infrageneric classification and molecular phylogeny of New World Croton (Euphorbiaceae). Taxon 2011; 60(3): 791-823.

[2] Salatino A, Salatino MLF, Negri G. Traditional uses, chemistry and pharmacology of Croton species (Euphorbiaceae). J Brazilian Chem Soc 2007; 18(1): 11-33. http://dx.doi.org/10.1590/S0103-50532007000100002

[3] Schmelzer GH, Gurib-Fakim A. Plant resources of tropical Africa 11(1): Medicinal plants 1. Wageningen: PROTA Foundation 2008. 
[4] Rahman AHMM, Akter M. Taxonomy and medicinal uses of Euphorbiaceae (Spurge) family of Rajshahi, Bangladesh. Res PI Sci 2013; 1(3): 74-80. https://doi.org/10.12691/plant-1-3-5

[5] Maroyi A. Traditional usage, phytochemistry and pharmacology of Croton sylvaticus Hochst. ex C. Krauss. Asian Pac J Trop Med 2017; 10: 423-429. https://doi.org/10.1016/j.apjtm.2017.05.002

[6] Maroyi A. Croton megalocarpus Hutch. in tropical Africa: phytochemistry, pharmacology and medicinal potential. Res $\mathrm{J}$ Med PI 2017; 11: 124-133. https://doi.org/10.1155/2017/1694671

[7] Maroyi A. Ethnopharmacological uses, phytochemistry and pharmacological properties of Croton macrostachyus Hochst. ex Delile: a comprehensive review. Evidence Based Compl Altern Med 2017; Volume 2017, Article ID 1694671. https://doi.org/10.1155/2017/1694671

[8] Stuart KL. Chemical and biological investigations of the Croton genus. Revista Latinoam Quím 1970; 1: 140-147.

[9] Léonard J. Euphorbiaceae. In Robyns W, Staner P, Demaret F, Germain R, Gilbert G, Hauman L, et al. editors. Flore du Congo Belge et du Ruanda-Urundi. Spermatophytes. Volume 8, 1. Brussels: Institut National pour l'Étude Agronomique du Congo Belge 1962.

[10] Smith AR. Euphorbiaceae. In Polhill RM, editor. Flora of tropical East Africa. Rotterdam: AA Balkema 1987; pp. 20391.

[11] Heinze C, Ditsch B, et al. First ethnobotanical analysis of useful plants in Cuanza Norte, north Angola. Res Rev J Bot Sci 2017; 6(2): 44-53.

[12] Latham P. Useful plants of Bas-Congo province, Democratic Republic of Congo. London: Department for International Development 2004; p. 321.

[13] Latham P. Some honeybee plants of Bas-Congo province, Democratic Republic of Congo. London: Department for International Development 2005; p. 263.

[14] Longanga-Otshudi A, Vercruysse A, Foriers A. Contribution to the ethnobotanical, phytochemical and pharmacological studies of traditionally used medicinal plants in the treatment of dysentery and diarrhoea in Lomela area, Democratic Republic of Congo (DRC). J Ethnopharmacol 2000; 71(3): 411-423.

https://doi.org/10.1016/S0378-8741(00)00167-7

[15] Mbayo KM, Kalonda ME, et al. Contribution to ethnobotanical knowledge of some Euphorbiaceae used in traditional medicine in Lubumbashi and its surroundings (DRC). J Adv Bot Zool 2016; 4(2): 1-16. https://doi.org/10.15297/JALS.V4I2.01

[16] Tangenyi $\mathrm{OH}$. Contribution á l'étude des plantes médicinales utilisées contre le Paludisme au Sankuru. MSc Thesis, Patrice Emery Lumumba Methodist University, WemboNyama, Democratic Republic of Congo 1996.

[17] Mesia GK, Tona GL, et al. Antimalarial activities and toxicities of three plants used as traditional remedies for malaria in the Democratic Republic of Congo: Croton mubango, Nauclea pobeguinii and Pyrenacantha staudtii. Ann Trop Med Parasitol 2005; 99(4): 345-357. https://doi.org/10.1179/136485905X36325

[18] Mbuta KK, Mwima K, et al. Plantes médicinales de traditions. Province de l'Equateur, R.D. Congo, Kinshasa. Kinshasa: Institut de Recherche en Sciences de la Santé (I.R.S.S.) 2012.

[19] Watt JM, Breyer-Brandwijk MG. The medicinal and poisonous plants of southern and eastern Africa. Edinburgh: E and S Livingstone Ltd. 1962.

[20] Maroyi A. Traditional use of medicinal plants in south-central Zimbabwe: review and perspectives. J Ethnobiol Ethnomed 2013; 9: 31.

https://doi.org/10.1186/1746-4269-9-31
[21] Maroyi A. Treatment of diarrhoea using traditional medicines: contemporary research in South Africa and Zimbabwe. Afr J Trad Complem Altern Med 2016; 13: 5-10. http://dx.doi.org/10.21010/ajtcam.v13i6.2

[22] Semenya SS, Maroyi A. Medicinal plants used for the treatment of tuberculosis by Bapedi traditional healers in the Limpopo Province, South Africa. Afr J Trad Complem Altern Med 2013; 10: 316-323. http://dx.doi.org/10.4314/ajtcam.v10i2.17

[23] Van Wyk B-E, Van Oudtshoorn B, Gericke N. Medicinal plants of South Africa. Pretoria: Briza Publications 2013.

[24] Mahajan M, Kumar V, Yadav SK. Alkaloids: properties, applications and pharmacological effects. In Cassiano NM, editor, Alkaloids: Properties, applications and pharmacological effects, New York: Nova Science Publishers 2011; pp. 1-36.

[25] Rumalla CS, Jadhav AN, et al. Alkaloids from Heimia salicifolia. Phytochem 2008; 69(8): 1756-1762. https://doi.org/10.1016/j.phytochem.2008.01.028

[26] Adelekan AM, Prozesky EA, et al. Bioactive diterpenes and other constituents of Croton steenkampianus. J Nat Prod 2008; 71: 1919-1922.

https://doi.org/10.1021/np800333r

[27] Thongtan J, Kittakoop P, et al. New antimycobacterial and antimalarial 8,9-secokaurane diterpenes from Croton kongensis. J Nat Prod 2003; 66: 868-870. https://doi.org/10.1021/np030067a

[28] Attioua B, Bernard W, Philippe C. Antiplasmodial activity of constituents isolated from Croton lobatus. Pharmaceut Biol 2007; 45: 263-266. https://doi.org/10.1080/13880200701214607

[29] Franssen FFJ, Smeijsters LJJ, et al. In vivo and in vitro antiplasmodial activities of some plants traditionally used in Guatemala against malaria. Antimicrobial Agents Chemoth 1997; 41: 1500-1503.

[30] Prozesky EA, Meyer JJM, Louw IA. In vitro antiplasmodial activity and cytotoxicity of ethnobotanically selected South African plants. J Ethnopharmacol 2001; 76: 239-245. https://doi.org/10.1016/S0378-8741(01)00245-8

[31] Weniger B, Lagnika L, et al. Evaluation of ethnobotanically selected Benin medicinal plants for their in vivo antiplasmodial activity. J Ethnopharmacol 2004; 80: 279-284. https://doi.org/10.1016/j.jep.2003.10.002

[32] Garavito G, Rincon J, et al. Antimalarial activity of some Colombian medicinal plants. J Ethnopharmacol 2006; 107: 460-462.

https://doi.org/10.1016/j.jep.2006.03.033

[33] Okokon JE, Nwafor PA. Antiplasmodial activity of root extract and fractions of Croton zambesicus. J Ethnopharmacol 2009; 121: 74-78. https://doi.org/10.1016/j.jep.2008.09.034

[34] Mohammed T, Erko B, Giday M. Evaluation of antimalarial activity of leaves of Acokanthera schimperi and Croton macrostachyus against Plasmodium berghei in Swiss albino mice. BMC Complem Altern Med 2014; 14: 314. https://doi.org/10.1186/1472-6882-14-314

[35] Rodriguez JA, Haun M. Cytotoxicity of trans-dehydrocrotonin from Croton cajucara on V79 cells and rat hepatocytes. PI Med 1999; 65: 1-5.

https://doi.org/10.1055/s-1999-14008

[36] Block S, Stevigny C, et al. Ent-trachyloban-3-beta-ol, a new cytotoxic diterpene from Croton zambesicus. PI Med 2002; 68: 647-649. https://doi.org/10.1055/s-2002-32903

[37] Melo PS, Duran N, Haun M. Derivatives of dehydrocrotonin, a diterpene lactone isolated from Croton cajacura: cytotoxicity in rat cultured hepatocytes and in V79 cells. Hum Exp Toxicol 2002; 21: 281-288.

https://doi.org/10.1191/0960327102ht246oa 
[38] De Almeida ABA, Melo PS, et al. Antiulcerogenic effect and cytotoxic activity of semi-synthetic crotonin obtained from Croton cajucara Benth. Eur J Pharmacol 2003; 472: 205-212. https://doi.org/10.1016/S0014-2999(03)01909-5

[39] Friere ACG, Melo PD, et al. Cytotoxic effect of the diterpene lactone dehydrocrotonin from Croton cajucara on human promyelocytic leukemia cells. PI Med 2003; 60: 67-69. https://doi.org/10.1055/s-2003-37036

[40] Gadir AWS, Onsa TO, et al. Comparative toxicity of Croton macrostachys, Jatropha curcas and Piper abyssinica seeds in Nubian goats. Small Rum Res 2003; 48: 61-67. https://doi.org/10.1016/S0921-4488(02)00181-5 